\title{
Adómorál, bizalom és kényszerek - adózási motivációk Magyarországon korrupciós botrányok idején
}

\begin{abstract}
A viselkedési közgazdaságtani és a gazdaságpszichológiai kutatások szerint az adózási magatartást részben kényszerü, részben önkéntes motivációk, az adómorál alakítják. Tanulmányunk ezekre a megközelítésekre összpontosít, tudomásunk szerint ez az első hazai kutatás, amely az intézményi bizalomnak és az eljárási méltányosságnak az adófizetési attitüdökkel kapcsolatos összefüggéseit elemzi. Két - 2013-ban, illetve 2015-ben készült - reprezentatív felmérés alapján vizsgáljuk a magyar állampolgárok adózási motivációit. Az adatfelvételek időpontjának sajátossága, hogy a köztes időszakban az adóhatóság (NAV) müködését korrupciós botrányok árnyékolták be. Várakozásunknak megfelelően az intézményi bizalom gyengesége és az észlelt korrupció jelentősen rombolják az adómorált, miközben a kényszerü adófizetést nem befolyásolják érdemben. Vizsgálatunk hipotézisünket cáfoló eredménye, hogy az önkéntes adófizetési hajlandóság Magyarországon is erősebb a kényszerünél. Végül hipotézisünkkel összhangban szignifikáns és az egyéb tényezőktől függetlenül is kimutatható a NAV-botrányok negatív hatása az adóhatóság iránti bizalomra.*

Journal of Economic Literature (JEL) kód: B25, H26, P16.
\end{abstract}

A tanulmányban először ismertetjük az adózási magatartással kapcsolatos fontosabb megközelítéseket. Az empirikus kutatás fogalmi megalapozása érdekében a kényszerü és az önkéntes adózási hajlandóság okaira koncentrálunk, és áttekintjük az

* A kutatást az OTKA K 101701. számú projektje támogatta. A tanulmány alapjául szolgáló kutatás néhány előzetes eredményét a szerzők előadták az MTA TK Politikatudományi Intézetében, a 2. International Conference on Public Policy konferencián (Milánó, 2015. július 1-4.), továbbá megjelent egy kötet fejezeteként (Boda-Bartha [2015]). A jelenlegi tanulmány elméleti kereteit és módszertanát tekintve is jelentősen eltér a korábbi verzióktól. Köszönjük anonim bírálóinknak, intézeti kollégáinknak, illetve Geert Bouckaertnek (Public Governance Institute, KU Leuven) és Szilágyi Katalinnak (OGResearch Budapest), hogy kritikai észrevételeikkel segítették a tanulmány fejlődését. A fennmaradó hibákért kizárólag a szerzőket terheli felelősség.

Bartha Attila, MTA TK Politikatudományi Intézet és IBS Budapest (e-mail: bartha.attila@tk.mta.hu, abartha@ibs-b.hu),

Boda Zsolt, MTA TK Politikatudományi Intézet és Budapesti Corvinus Egyetem Gazdaságetikai Központ (e-mail: boda.zsolt@tk.mta.hu).

A kézirat első változata 2016. május 27-én érkezett szerkesztőségünkbe.

DOI: http://dx.doi.org/10.18414/KSZ.2016.10.1021 
ezzel kapcsolatos elméleti tanulságokat és korábbi kutatási eredményeket. Ezt követően a kérdés magyarországi relevanciáját és kontextusát tárgyaljuk, majd megfogalmazzuk empirikus vizsgálatunk kutatási kérdéseit és hipotéziseit, operacionalizáljuk az elemzendő változókat, továbbá bemutatjuk az empirikus elemzés adathátterét és vizsgálati módszereinket. Ezután ismertetjük eredményeinket, végül tanulmányunkat a magyarországi empíriából adódó általánosabb következtetésekkel zárjuk.

\section{Adófizetés, adómorál és adózási motivációk}

Az adózási magatartásra vonatkozó közgazdasági elméletek középpontjában hosszú időn keresztül az adócsalás problémája állt. A bünözés közgazdaságtanának Becker [1968] írására visszanyúló megközelítése nyomán Allingham-Sandmo [1972] elméleti tanulmánya volt a mérvadó, amely szerint az adócsalás pozitív várható hasznosságú, de magas kockázatú viselkedési döntésként értelmezhető. Későbbi kutatások (Alm és szerzőtársai [1992], Slemrod-Yitzhaki [2002]) rámutattak, hogy a leleplezés valószínűségéből és a büntetési tételek mértékéből lényegesen nagyobb mértékü adócsalás adódna annál, mint ami empirikusan megfigyelhető. Az adófizetés így az önérdekkövető magatartást tételező nem kooperatív játékelméleti perspektívából igazi rejtély (Andreoni és szerzőtársai [1998]). Feld-Frey [2007] ráadásul felhívták a figyelmet arra, hogy az adófizetés nem vezethető vissza az adófizetők szélsőségesen kockázatkerülő habitusára sem - ezt a feltevést ugyanis az empirikus kutatási eredmények nem támasztják alá. Az adófizetést tehát társadalmi viselkedésként célszerü értelmeznünk, és a valódi kérdés az, hogy milyen mechanizmusok alakítják ezt a pusztán racionális motívumokkal nem magyarázható - Ariely [2008] híres könyvének címét idézve „kiszámíthatóan irracionális” - magatartást.

Az intézményi közgazdaságtan perspektívájából az adófizetés az adófizetők és az adóhatóság közötti kölcsönös tiszteleten és őszinteségen alapuló pszichológiai szerződésként fogható fel (Feld-Frey [2002], [2007]), így az állampolgárok adófizetési hajlandósága elsősorban azon múlik, hogy legitimnek és méltányosnak tartják-e a politikai döntéshozatalt. Ha ez fennáll, és a politikai közösség tagjai általában bíznak intézményeikben, illetve specifikusan az adóhatóságban, akkor befizetik adóikat; akkor is, ha a közjavakból hozzájárulásuknál kevésbé részesednek (Györffy [2012] 420. o.). Ez a felfogás összhangban áll a viselkedési közgazdaságtan társadalmipreferencia-megközelítésével. A társadalmi preferenciák ugyanakkor reagálnak a politikai döntéshozók viselkedésére, így részben a hatalmi és a közpolitikai döntések következményei (Bowles-Hwang [2008] 1817. o.).

A viselkedési közgazdaságtanban azonban más értelmezés is adódik az adófizetők normakövető, altruizmusnak vagy reciprocitásnak tekinthető viselkedéséről. Méder és szerzőtársai [2012] (1104. o.) az adófizetök társadalmi viselkedésének megértésére a társadalmi preferenciák mellett a korlátozottan racionális, gyors és takarékos heurisztikák nyomán cselekvő állampolgár modelljét (Gigerenzer és szerzőtársai [1999]) is alkalmazták, és ellentmondásos következtetésekre jutottak. Eredményeik szerint ugyanis heurisztikus viselkedésü aktorokat feltételezve „a nem optimalizáló 
ágenseket könyörtelenül kihasználhatnak a rossz hatékonyságú vagy rosszindulatú kormányzatok" (Méder és szerzőtársai [2012] 1104. o.). Más megfogalmazásban: a stabil társadalmi preferenciák feltevését feladva, heurisztikus cselekvők esetén a politikai hatalom az elfogultságok és az értelmezési keretek (biases and frames) alakításának széles tárházával rendelkezik az adófizetés biztosítására.

Az elmúlt másfél évtizedben az adózási viselkedés empirikus vizsgálatakor a közgazdaságtan nagymértékben integrálta a többi társadalomtudomány, elsősorban a gazdaságpszichológia idevágó eredményeit. Kirchler [2007] az adózási magatartás gazdaságpszichológiai recepcióját áttekintő monográfiájában a viselkedési közgazdaságtan és a gazdaságpszichológia közötti kölcsönös megtermékenyítő hatásra mutat rá. Jól jellemzi ezt, hogy az adómorál (tax morale) eredetileg Schmölders [1960] munkásságához köthető fogalma mindenekelőtt Bruno Frey és szerzőtársai kutatásai révén az adózási magatartás egyik vizsgálandó attribútuma lett az empirikus közgazdaságtani munkákban is (FreyWeck-Hannemann [1984], Feld-Frey [2002], [2007], Frey-Torgler [2007]). Az adómorál konceptualizálása látszólag egyszerü: Feld-Frey [2002] (88. o.) az adómorált az adófizetők belső adófizetési késztetéseként határozza meg, és ennek feleltethető meg TorglerSchneider [2007] (444. o.) definíciója is, amelyben a szerzők az adómorált a közjavakhoz történő hozzájárulás erkölcsi kötelezettségeként értelmezik. Ennek kapcsán ugyanakkor Méder és szerzötársai [2012], illetve Simonovits [2013] felhívja a figyelmet arra, hogy egyéni szinten az adómorál nemcsak exogén (a hasznossági függvény egyik paramétere, azaz az adófizetők adott belső késztetése) lehet, hanem endogén is, mivel az adózók referenciacsoportjában észlelt adózási viselkedéstől is függ.

Az adómorállal kapcsolatos kutatások közgazdasági relevanciáját sokáig kérdésessé tette az adómorál mint adófizetői attitüd és a tényleges adófizetés közötti kapcsolat bizonytalan természete. Halla [2012] elemzése azonban meggyőzően demonstrálta, hogy az adómorál az adófizetői viselkedés egyik fontos magyarázó változója lehet. Ennek ellenére helytelen lenne az adómorál tényezőjének túlértékelése az adófizetésben: az elmélet mellett az empíria is azt támasztja alá, hogy az adómorál mellett a szokásos gazdasági ösztönzők is szignifikánsan hatnak az adózási magatartásra (Halla [2012] 20. o.).

\section{Hatósági kontroll és intézményi bizalom}

Mindezzel összhangban Braithwaite [2002] nyomán az adófizetés kétféle motivációját különböztethetjük meg: a morális elkötelezödésböl fakadó önkéntes adófizetés, illetve a legitim hatalomnak történő alávetettség kényszerü motivációját. A kényszerủ és az önkéntes adózási motivációk közötti kapcsolat ugyanakkor ellentmondásos: bár a hatékonyan müködő adóhatóság tól való félelem ösztönözheti az adófizetést, Kahan [2001] rámutatott, hogy a szankciók (indokolatlannak vélt) növelése csökkentheti is az adózási hajlandóságot, mivel gyengíti az állampolgárok együttmüködési készségét az adóhatósággal.

Az adófizetés kétféle motivációját Kirchler és szerzőtársai [2008], illetve Muehlbacher és szerzőtársai [2011] a csúszós lejtő (slippery slope) értelmezési keretében tárgyalták: e 
szerint a kényszerű motivációt a hatalom, azaz az adóhatóság tetten érési és szankcionális képességétől való félelem, az önkéntes motivációt pedig a közintézményekbe, mindenekelőtt az adóhatóságba vetett bizalom alakítja. Magas bizalomszint mellett a kényszerü motivációk szerepe csekély, hiszen az adófizetés önkéntes késztetése a hatalomtól függetlenül is müködik. Ha pedig az adóhatóság elrettentési képessége maximális, akkor az önkéntes adózási motivációk súlya válik lényegtelenné.

Frey [1997] kiszorítási tézise szerint a külső, kényszerü és a belső, önkéntes motivációk közötti helyettesítés effektív korlátja, hogy a külső motivációk jellemzően csökkentik a belsőket, így a szankciók növelése esetén a teljes hatás akár negatív is lehet az adófizetésre. Feld-Frey [2007] ugyanakkor rámutat, hogy a kényszer, azaz a szankcionálás lehetősége az adózással kapcsolatos társadalmi szerződés betartatásának garanciájaként értelmeződik azok számára is, akik belső készetés alapján is hajlandók adózni. Vagyis miközben a túlzott szankció a méltánytalanság, a szankció és a végrehajtás hiánya az igazságtalanság érzetét keltheti.

\section{Eljárási méltányosság és az államhatalommal kapcsolatos attitüdök}

Akerlof-Shiller [2009] viselkedési közgazdaságtani alapműve óta az empirikus közgazdasági kutatások magától értetődő módon tételezik fel a cselekvés lehetséges mozgatójaként a méltányosság (fairness) motívumát - az adózással, illetve általában a jogkövető magatartással foglalkozó vizsgálatok pedig Tyler [1990] nyomán már korábban is nagy figyelmet szenteltek az intézmények méltányosságával kapcsolatos percepcióknak. Tyler [1990] és [2011] érvelése szerint az emberek alapvetően nem azért tartják be a jogszabályokat, mert félnek a szankcióktól, hanem mert bíznak a jogrendszerben és a hatóságokban; a bizalmat pedig nagymértékben meghatározza az intézményes eljárások méltányosságának (procedural fairness) érzékelése. Míg az önkényes, kiszámíthatatlan eljárások a méltánytalanság érzetét erősítik, addig az átlátható, konzisztens, az ügyfelek megbecsülésén alapuló és elfogulatlan döntéshozatal a méltányosság megnyilvánulásaként értelmeződik (vö. Leventhal [1980] és Tyler [2011]). Az eljárási méltányosság, a bizalom és a jogkövető magatartás összefüggéseit kimutatták a rendőrség és az igazságszolgáltatás müködése kapcsán (lásd például Hawdon [2008]), de az adófizetők és az adóhatóság kapcsolatában is (Hofmann és szerzötársai [2008], Hartner és szerzötársai [2008], Murphy [2004] és [2005], Wahl és szerzötársai [2010]).

Az adófizetési motivációkra ugyanakkor nemcsak az adóhatóság iránti bizalomnak és méltányossági percepcióknak van hatásuk, hanem a közintézményekkel, illetve a politikai hatalmat reprezentáló állammal kapcsolatos általánosabb attitüdöknek is. A demokratikus, a választói preferenciákra fogékonyabb, illetve kevésbé korruptnak érzékelt államok több adót szednek be (Bird és szerzőtársai [2008]), továbbá a közvetlen demokratikus eljárások elterjedtsége is növeli a közintézmények iránti bizalmat, így közvetve az adózási hajlandóságot is (Torgler [2005]). Mindennek kapcsán Hochman és szerzőtársai [2015] arra hívják fel a figyelmet, hogy míg az emocionális motívumok elsősorban az önkéntes adófizetésre hatnak, addig a racionálisként dekódolt üzenetek inkább a kényszerủ adófizetési motivációkat befolyásolják. 


\section{Egyéni jellemzők}

Az intézményi tényezők mellett az adómorált egyéni jellemzők is módosítják (Wenzel [2005]). Az altruistább és a közösségi értékek iránt elkötelezettebb emberek inkább motiváltak az adófizetésre (Braithwaite [2002]). Ugyanez igaz a vallásos emberekre és azokra is, akik erösebben azonosulnak politikai közösségükkel, illetve büszkék társadalmi identitásukra (Torgler-Schneider [2007], Konrad-Qari [2012]). Ami a társadalmi-demográfiai változókat illeti, a nemzetközi összehasonlító felmérések alapján készült elemzések ellentmondásos eredményekre jutnak; a politikai hatalom és az intézményi bizalom kontextusa országonként másként alakítja a társadalmi-demográfiai tényezők hatását az adómorálra (Hanousek-Palda [2004], Torgler-Schneider [2007], Lago-Peñas-Lago-Peñas [2010]). A hatalom és a bizalom kontextuális hatására mutat rá egy magyar, orosz, osztrák és román egyetemi hallgatók adómorálját kísérleti módszerrel vizsgáló kutatás is (Kogler és szerzőtársai [2013]), bár ennek eredményei a mintavétel sajátossága miatt legfeljebb korlátozottan általánosíthatók. ${ }^{1}$ A kelet-közép-európai országok esetében mindenesetre általában érvényes, hogy a nőknek, az idősebbeknek és az iskolázottabbaknak erősebb az önkéntes adófizetési motivációja (Torgler [2012]). A jövedelemi biztonság pozitív hatása az adómorálra ugyancsak robusztus összefüggésnek tủnik (Lago-Peñas-Lago-Peñas [2010]). Végül a történeti szocializációs háttér hatása az egyének pszichológiai jellemzőire is világosan kimutatható, és bár nem kelet-közép-európai országokban zajlott Andrighetto és szerzőtársai [2016] kísérleti kutatása, néhány eredménye térségünkre nézve is érvényes. A szerzők az olasz és a svéd állampolgárok adózási attitűdjeit vizsgálva arra a következtetésre jutottak, hogy miközben a két országban átlagosan hasonló az egyének csalási hajlama, az olasz állampolgárok között lényegesen elterjedtebb az Ariely [2012] által kozmetikázásnak (fudging) nevezett beállítódás, ami magától értetődően negatív hatású az adómorálra (és általában a társadalmi viselkedésre).

\section{Az adómorál, az intézményi bizalom és hatalom magyarországi háttere}

Az adózási motivációkkal és a magyarországi adómorállal kapcsolatos kérdéseket - jellemzően akut gazdaságpolitikai problémaként aposztrofálva - már a kilencvenes évektől felvetették a magyar közgazdászok. Két évtizeddel ezelött például Kornai János így írt erről: „... ha egyáltalán változik az adómorál, akkor az sokaknál inkább még rosszabbra fordul. A diktatórikus államtól jobban féltek a jogszabályok megsértői.... Nem maroknyi adócsaló ármánykodik, akit a szigorú adóhatóság nem túl nagy fáradsággal leleplezhetne. ... Szinte az egész magyar lakosság aktívan vagy hallgatólagosan közremüködik." (Kornai [1996] 10-11. o.) Kornai, bár más szavakkal, de éppen a kozmetikázásra való hajlam általános elterjedtségét ostorozta, és ennek az adómorálra gyakorolt negatív hatásait érzékeltette. Korabeli megítélés szerint a gyenge magyarországi adómorál a kétezres években is a gazdaságpolitika kritikus területe

\footnotetext{
${ }^{1}$ Kizárólag egyetemi hallgatókat kérdeztek meg a felmérések során.
} 
maradt - például a rejtett gazdaság elleni fellépés során (Szántó-Tóth [2001]) vagy az adóreformok tervezésekor, a közvetlen és a közvetett adók arányának megválasztásában (Benedek-Lelkes [2006]).

$\mathrm{Az}$ adófizetés és az adómorál kérdései a hazai közgazdasági kutatások számára ma is kiemelten fontosak: a Köz-Gazdaság Tudományos Füzeteknek az adópolitikáról szóló 2014. decemberi különszámában megjelent tanulmányok specifikusan a magyar adórendszer, illetve az adózás hatékonyságának problémáival foglalkoznak. Az ott megjelent tanulmányok közül Bánfi [2014] az adórendszer méltányos müködését és az adófizetés etikai motivációit elmélettörténeti keretben, illetve a kortárs közpénzügyi irodalomba beágyazottan tárgyalja, Pesuth [2014] pedig a pénzügyi szektor különadója kapcsán elemzi az adózás méltányosságának percepciós kérdéseit. Ugyancsak az adómorál javításának lehetőségeivel foglalkozik Gulyás és szerzőtársai [2015] műhelytanulmánya. A szerzők a TAKSIM ágensalapú szimulációs modell segítségével vizsgálták az adófizetést érintő döntések motivációit. ${ }^{2}$ Megállapításuk szerint az adózási morál javítása és az adócsalás megfékezése az ellenőrzések gyakoriságának és pontosságának javítása mellett adaptív adóellenőrzési stratégiával, továbbá a munkanélküliség csökkentésével és a kormányzati szolgáltatások jobb minőségével is ösztönözhető (Gulyás és szerzőtársai [2015] 41. o.).

A közelmúlt gazdaságpolitikai lépései és politikai történései ugyanakkor néhány új empirikus elemzési szempontot is felvetnek a hazai adómorállal, az intézményi bizalommal, illetve a hatalmi kényszerekkel kapcsolatban. Egyrészt az elmúlt évek adópolitikai lépései során a magyar kormányzat elsősorban az ellenőrzések szigorításával, a Nemzeti Adó- és Vámhivatal (NAV) adóbeszedési képességének javításával kívánta erősíteni az adózási hajlandóságot. Kormányzati jelentések szerint az adófizetési hajlandóság javult; ezt a hivatalos források a fokozott ellenőrzések mellett főként annak tulajdonították, hogy a vállalkozásoknak a hagyományos pénztárgépeket kötelezően le kellett cserélniük a NAV információs rendszeréhez bekötött online pénztárgépekkel. ${ }^{3}$ 2016 elején viszont fordulat mutatkozik a kormányzati adópolitikai megnyilvánulásokban, és szándék tapasztalható az adóhatóságba vetett bizalom erősítésére ${ }^{4}$ is a vélelmezett adócsalók fokozott kontrollja, szankciókkal történő elrettentése mellett. ${ }^{5}$

A magyar állampolgárok és az adóhatóság közötti bizalmi viszonyt ugyanakkor az elmúlt években súlyos korrupciós botrányok árnyékolták be. Az első nagyobb botrány

\footnotetext{
${ }^{2}$ A TAKSIM-modellben a munkáltató, a munkavállaló és a kormányzat magatartása is elemezhető.

${ }^{3}$ Erről tudósítottak az MTI 2015. március 25-i jelentése alapján a különböző hírforrások. Lásd például az origo.hu cikkét: A pénztárgépek miatt megugrott az adófizetés (http://www.origo.hu/ gazdasag/20150325-a-penztargepek-miatt-megugrott-az-adofizetes.html).

${ }^{4}$ Az MTI 2016. február 19-ei közleménye szerint Varga Mihály nemzetgazdasági miniszter a NAV átalakítása kapcsán arra hívta fel a figyelmet, hogy „olyan új adóhatóságot alakítanak ki, amely képes arra, hogy tevőlegesen segítse a magyar gazdaság fejlődését. Ezért az adóhivatalnak a jövőben partnerként kell támogatnia a vállalatokat abban, hogy jobban eligazodjanak az adózás kérdéseiben, hogy minél kisebb adminisztrációs teher nehezedjen rájuk, és hogy minél kisebb időráfordítással tehessenek eleget adókötelezettségeiknek. A kitűzött cél nem lehet más, mint a svéd modell elérése, ahol a közigazgatási szervek népszerüségi listájának élén az adóhivatal áll.” (Lásd http://ado.hu/rovatok/ado/ egyszerusitene-az-adoeljarast-a-kormany.)

${ }^{5}$ Az időtáv rövidsége miatt ennek a retorikai fordulatnak a valódi jelentőségét egyelöre nem tudjuk empirikusan elemezni és így érdemben megítélni sem.
} 
során 2013 novemberében Horváth András, a NAV egykori adóellenőre azzal az állítással lépett a nyilvánosság elé, hogy a magyar adóhatóság immár több éve ezermilliárd forintos nagyságrendủ áfacsalásokhoz asszisztál. ${ }^{6}$ Ezek a vádak azonban nem egyértelműen bizonyítottak, és ennek a botránynak önmagában nem lett komolyabb politikai hatása sem. Egy évvel később viszont újabb botrány árnyékolta be a magyar adóhatóság müködését: korrupciós vádakra hivatkozva Vida Ildikót, a NAV akkori elnökét (több más kormányhivatalnok mellett) kitiltották az Egyesült Államokból. A botrány ezúttal közvetlen politikai következményekkel járt: a magyar kormányzat ellen tömegtüntetések szerveződtek, amelyek egyik fö témája az adóhatósággal is kapcsolatos korrupció volt. ${ }^{7}$ Az eset médiavisszhangja ugyancsak jelentősnek bizonyult: egy hat hónappal későbbi felmérés szerint a magyar népesség közel 90 százalékának volt tudomása erről az ügyröl (Boda-Bartha [2015]).

Mindezek alapján a botrányoknak az adóhatóságba vetett bizalmat és az önkéntes adófizetési hajlandóságot vélhetően romboló, illetve a szankcióktól való félelemnek a kényszerủ adófizetési hajlandóságot növelő hatását is vizsgáljuk a magyar állampolgárok adófizetési hajlandóságára. Az ágensalapú modellezésre épülö, illetve az adómorállal kapcsolatos, már hivatkozott hazai közgazdasági kutatások természetszerủen csupán korlátozottan integrálták azokat a politikai gazdaságtani, illetve gazdaságpszichológiai megközelítéseket, amelyek az intézményi bizalom perspektívájából vizsgálják az állampolgárok adófizetési hajlandóságát. Ismeretesek ugyanakkor olyan nemzetközi összehasonlító felméréseken alapuló kutatások, amelyek a magyar adómorálról ilyen megközelítésben vontak le következtetéseket; azaz a szankcióktól való félelem kényszerű motivációja mellett a magyarországi adófizetés önkéntességének mozgatóit is vizsgálták. Hanousek-Palda [2004], illetve Torgler [2003] és [2012] szerint a megkérdezettek jogrendszerbe vetett bizalma, demokratikus elkötelezettsége és a gazdasági helyzettel való elégedettsége pozitívan hat az önkéntes adózási hajlandóságra a kelet-közép-európai térség országaiban is. Ezeknek az adatfelvételeknek a változói ugyanakkor kevéssé alkalmasak az adófizetési motivációk finomabb, nemzeti összefüggésekbe ágyazott megragadására. ${ }^{8}$ Elemzésünk így vélhetően úttörő abban az értelemben, hogy a magyar állampolgárok adózási

\footnotetext{
${ }^{6}$ Horváth szerint az utóbbi években egyrészt elmaradtak az áfavisszaélésekkel kapcsolatos ellenörzések, ráadásul a NAV-on belül fel is számolták azt a csoportot, amely korábban képes volt a bonyolultabb adócsalások felderítésére. A NAV azonnal cáfolta a vádakat; Horváth Andrást ráadásul jogosulatlan információszerzéssel vádolták meg, a kapcsolódó házkutatás során pedig a hatóságok magukhoz vonták azt a zöld dossziét, amelyben Horváth állítása szerint a bizonyítékul szolgáló iratokat tárolta (http://atlatszo.hu/2013/11/19/horvath-andras-mar-ket-eve-milliardos-szamlagyarakrafigyelmeztette-a-fideszt/; http://index.hu/gazdasag/2013/11/28/nav_sajtaj).

Vida Ildikó 2015. május 20-án lemondásra kényszerült hivatali tisztéről, majd távozott a NAV elnöki pozíciójából.

${ }^{8}$ A nemzetközi kérdőíves adatfelvételek alapján levont következtetések időnként kétségeket keltenek. Torgler [2012] például a World Values Survey (WVS) adatai alapján arra a következtetésre jut, hogy a kétezres évtizedben a régióban mindenhol romlott az adómorál - éppen Magyarországot leszámítva, ahol a legkedvezőbb ennek az értéke (Magyarországot e szerint az elemzés szerint közvetlenül Bulgária követi). Maga a szerző is a fenntartásainak ad hangot adataival kapcsolatban, és a magunk részéről osztozunk ezekben a kétségekben, tudva, hogy a WVS-adatok problémáira más elemzések is rámutattak (lásd Donnelly-Pop-Eleches [2012]).
} 
hajlandóságában az adóhatóságba vetett bizalom mögöttes tényezőire koncentrál. Bár az elemzés empirikus adatháttere csupán Magyarországra vonatkozik, kutatási eredményeink részben általánosíthatók a kelet-közép-európai térségre, ahol hasonló országtanulmány ismereteink szerint még nem készült.

\section{Kutatási kérdések, hipotézisek, adatok és elemzési módszerek}

A tanulmány tehát a magyar állampolgárok önkéntes, illetve kényszerủ adózási hajlandóságát elemezve a következő kérdésekre keresi a választ. 1. Milyen az önkéntes, illetve a szankcióktól való félelem miatti kényszerű motivációk egymáshoz viszonyított súlya a magyar állampolgárok adófizetési attitüdjében? 2. Mennyire jelentősek az intézményi bizalom és a procedurális méltányosság tényezői a magyar állampolgárok önkéntes adózási hajlandóságának alakításában? 3. Milyen tényezők hatnak a kényszerü adófizetésre? 4. Milyen hatása volt a NAV-hoz is köthető korrupciós botrányoknak az adózási attitüdökre?

Az empirikus elemzés során a következő hipotéziseket teszteljük.

1. HIPOTÉZIs • Magyarországon az adózás kényszerü motivációi jelentősebb hatással vannak az adózási attitüdökre, mint az önkéntes adózási motivációk.

Kétségtelen, hogy nyugat-európai és amerikai vizsgálatok szerint az önkéntes, illetve a társadalmi okokra visszavezethető adófizetési motivációk erősebb hatást gyakorolnak az adózási attitüdökre, mint a szankcióktól való félelem kényszerü motívumai. Magyarország ugyanakkor nemzetközi összehasonlításban mérsékelt szintü bizalommal jellemezhető társadalom (Kogler és szerzötársai [2013], Boda-MedveBálint [2014]), ahol ekképpen az állampolgároknak a közintézmények iránti kooperációs attitűdjei is gyengébbek. Ez alapján azt várhatjuk, hogy a kényszerü motivációk Magyarországon jelentősebb szerepet játszanak az adózási motivációk között, mint a fejlettebb országokban.

2. HIPOTÉZIS • Az adóhatóságba vetett bizalom, illetve az adóhatósággal kapcsolatos procedurális méltányosság tényezöi szignifikáns hatást gyakorolnak az önkéntes adófizetési motivációkra.

Várakozásunk az, hogy az intézményi bizalom és a procedurális méltányosság szerepe az önkéntes adófizetési motivációk magyarországi körülményei között is jelentős. Hipotézisünk azt is tartalmazza, hogy nem csupán önmagukban szignifikánsak ezek a tényezők, hanem az adófizetési motivációkra szintén hatást gyakorló, szokásosan használt társadalmi-demográfiai változókhoz képest is.

3. нIроте́ZIS • A kényszerü adófizetési motivációkat az adóhatóság észlelt hatékonysága befolyásolja elsősorban.

A kényszerủ adófizetési motivációknál ugyanakkor kevésbé várható az adómorált alakító bizalmi és méltányossági tényezők szerepe, ebben az esetben a szokásos társadalmi-demográfiai változók mellett várhatóan inkább az intézményi hatékonyság, azaz az adócsalók elleni szankcionálási képesség percepciója számít.

4. HIPOTÉZIs • A közelmúltban történt, a magyar adóhatósághoz köthetö botrányok szignifikáns negatív hatást gyakoroltak az adóhatóságba vetett bizalomra. 
Várható, hogy a korrupciós botrányok önmagukban negatív hatásúak az adóhatóságba vetett bizalom mértékére (függetlenül attól, hogy a NAV miben marasztalható el valójában). A hipotézis szerint a botrányok után - a botrányok előtti idöszakhoz képest - kimutatható egy olyan, a botrányok percepcióját tükröző tényezö, amely a társadalmi-demográfiai tényezőktől, a bizalomtól, az eljárási méltányosságtól és a NAV vélelmezett hatékonyságától függetlenül is szignifikáns negatív hatást fejt ki az adóhatóságba vetett bizalomra.

Empirikus elemzésünk adatforrását két adatfelvétel biztosítja: az adatgyüjtésekre 2013 októberében, illetve 2015 márciusában személyes megkérdezés formájában került sor. Mindkét adatfelvétel reprezentatív a magyar felnőtt népességre ${ }^{9}$ nem, életkor és iskolai végzettség szerint. ${ }^{10} \mathrm{Az}$ adatfelvételi kérdőívek részben azonosak voltak. A 2015-ös kérdőív ugyanakkor tartalmazott a NAV korrupciós botrányaira utaló kérdéseket is, amelyekre a 2013-as kérdőív még értelemszerűen nem reflektált. Ezenkívül a későbbi adatfelvételben explicit kérdés formájában vizsgáltuk a kényszerü, illetve az önkéntes adófizetési motivációkat.

Empirikus elemzésünk függő változói így egyrészt a 2015-ös adatfelvételben specifikusan kérdezett kényszerü, illetve önkéntes adófizetési motivációk közelítő változói (proxyjai). A NAV-botrányok hatásának tesztelésére viszont az adóhatóságba vetett intézményi bizalom változóját használtuk függő változóként; ehhez a 2013-as és a 2015-ös adatfelvételek közös változóihoz tartozó adatokat egy adatbázisban egyesítettük. A NAV-ba vetett intézményi bizalom változója ugyanakkor magyarázó változóként szerepelt az adófizetési hajlandóság vizsgálata során.

A kényszerü adófizetés motivációját (TAX_CONSTRAINED) a következő állítással történő egyetértés mértékével közelítettük: „Ugyan nem szívesen fizetek adót, de félek az adóhatóság szigorú büntetésétől”. Az egyetértés mértékét válaszadóink 1-től 5 -ig terjedő skálán értékelték (ahol az 1 az „egyáltalán nem értek egyet”, az 5 pedig a „teljes mértékben egyetértek” opciót jelentette). Ugyanilyen 1-töl 5-ig terjedő egyetértési skálán mértük az önkéntes adófizetés motivációját (TAX_VOLUNTARY) is, ez esetben a következő állítással történő egyetértést vizsgáltuk: „Elfogadom, hogy adót kell fizetnem, hiszen az adókból fedezzük a közfeladatokat”. A magyar

\footnotetext{
${ }^{9}$ Tudatában vagyunk annak, hogy az egyes állampolgárok adófizetésének választási szabadságfoka jelentősen különböző. Az adózási döntéseknél a normaszegés lehetősége kétségkívül adott például a vállalkozóknál, miközben ez gyakorlatilag igen korlátozott az alkalmazottak vagy a nyugdíjasok esetében. Valamennyi felnőtt magyar állampolgár adózási magatartása azonban lehet normaszegő, például a vásárláskor történő számla kérésének elmulasztásakor vagy a háztartási javítási-szerelési szolgáltatások számla- és így forgalmiadó-mentes igénybevételekor. Ráadásul, míg kérdőíves adatfelvételekkel a tényleges adózási magatartás aligha mérhető érvényesen, az adómorált alakító attitűdök, motivációk viszonylag jól közelíthetők, azaz a mi vizsgálatunk érvényessége kevésbé korlátozott.

${ }^{10}$ Mindkét adatfelvétel mintája 1200 válaszadót tartalmazott. A megfigyelések kiválasztása 120 azonos népességű területi mintavételi egységből véletlen mintavételi eljárással történt. A kérdezőbiztosok minden területi mintavételi egységben 10 véletlenszerűen felkeresett háztartásból a felnőtt (18 évesnél idősebb) állampolgárokat kérdezték meg, a Leslie Kish-formula szelekciós elve alapján. Válaszmegtagadás esetén a hiányzó megfigyelés helyébe ugyanabból a területi mintavételi egységből egy másik véletlenül kiválasztott háztartás került. Ez az eljárás az adott területi mintavételi egység kvótájának eléréséig folytatódott. Az adatfelvételeket a Medián Közvélemény- és Piackutató Intézet készítette.
} 
adóhatóságba vetett bizalom változóját (TRUST_NTCA) 11-fokú Likert-skálán mértük (a bizalom mértékét 0 -tól 10-ig kódoltuk). ${ }^{11}$

A független változókat a következők szerint operacionalizáltuk.

A társadalmi-demográfiai változók közül a GENDER változó értéke 1 volt a női válaszadóknál, és 0 a férfiaknál. Az AGE változó a válaszadó életkorát mutatja, az AGECAT ugyancsak az életkor kifejezője, de kategoriális formában, négy életkori csoportra bontva (18-34 évesek, 35-49 évesek, 50-64 évesek és 65 évnél idősebbek). Az iskolázottság mérésére használt EDUCATION olyan vakváltozó, amelynek értéke 1, ha a válaszadó legalább érettségizett, és 0 , ha iskolai végzettsége ennél alacsonyabb; aZ URBAN pedig olyan vakváltozó, amelynek értéke 1 , ha a válaszadó városi lakos, 0 akkor, ha nem városi településen él. Az anyagi helyzet mérése általában problematikus a kérdőíves adatfelvételeknél - ezt a megállapítást a mi adatfelvételeink is megerösítik. 2015-ben a jövedelmi pozícióval kapcsolatos explicit kérdésre kiugró mértékü (33,2 százalékos) volt a válaszmegtagadás, de a háztartások jövedelem szerinti csoportokba (alsó, alsó-közép, felső-közép, illetve felső jövedelmi rétegekbe) történő önbesorolására vonatkozó kérdésünk is hasonlóan magas, kereken 33 százalékos válaszhiánnyal járt. Azt viszont, hogy a háztartások jövedelmi helyzete hogyan alakult a közelmúltban, jól tudtuk mérni: ebben az esetben a válaszhiány mindössze 0,3 százalék volt. Így végül a jövedelmi helyzet változását használtuk a jövedelmi hatás mérésének közelítő változójaként: az INCOME_CHANGE_1Y változó ötfokú skálán mérte, hogy a válaszadó percepciója szerint háztartásának anyagi helyzet hogyan alakult az elmúlt 12 hónap folyamán. A kódolás során az 1 értéket a „sokat romlott” opcióhoz, az 5 értéket pedig a ,sokat javult” opcióhoz rendeltük.

A magyar adóhatóság kényszerítő képességét a NAV észlelt hatékonyságának változójával (NTCA_EFFECTIVENESs) közelítettük, amelyet a következő állítás fejezett ki: „Az adócsalókat jó eséllyel lebuktatja az adóhatóság”. A válaszokat az egyetértés mértéke szerint kódoltuk, ahol az 1 az „egyáltalán nem értek egyet”, az 5 pedig a „teljes mértékben egyetértek" opciót jelentette. Annak operacionalizálása során, hogy az állampolgárok percepciója szerint a NAV gyakorlata mennyiben követi a procedurális méltányosság elveit, G. S. Leventhal, illetve T. R. Tyler megközelítésére támaszkodtunk. Leventhal [1980] a procedurális méltányosság meghatározó komponenseinek a pártatlanságot és az egyenlő elbánást, vagyis a diszkriminációmentességet tekinti. Tyler [2011] ugyanakkor a szabályok konzisztens, mindenkire kiterjedő alkalmazását és az általános normakövetést tartja a procedurális méltányosság kulcstényezőinek. Az operacionalizálás során tehát olyan közelítő változókat kerestünk, amelyekkel megragadhatók az egyenlő, a konzisztens és a pártatlan elbánás megsértésének szempontjai. Így három közelítő változót használtunk annak mérésére, hogy a megkérdezettek véleménye szerint mennyiben érvényesül a procedurális méltányosság a NAV müködése során. Egyik változónk a diszkrimináció percepciója (DISCRIMINATION), amely a

\footnotetext{
${ }^{11}$ Felmerülhet a kérdés, hogy miért nem a magyar adatfelvételek során leggyakrabban előforduló (az iskolai osztályzatokkal analóg) ötfokú mérési skálát használtuk. Zmerli-Newton [2008] meggyőzően érvelnek amellett, hogy az attitüdök mérésekor célszerű a tágabb mérési skálák használata.
} 
válaszadók értékelése arról, hogy mennyire követik az egyenlő elbánás elvét az adóhatóságnál. Másik változónk a politikai befolyás percepciója (POLITICISATION), harmadik változónk pedig az észlelt korrupció mértéke, amelyet a megkérdezetteknek azon vélekedésével közelítettünk, hogy az adóhivatal munkatársai mennyiben hajlamosak kenőpénz elfogadására (CORRUPTION). Mindhárom változót 11-fokú Likert-skálán mértük (a jelenség percepciójának erösségét 0-tól 10-ig kódoltuk).

A korrupciós botrányok adózási attitűdökre gyakorolt hatásának vizsgálata további operacionalizálást igényelt. Ezt a parciális hatást az egyesített adatbázisban az idő dimenziójával tudtuk megragadni: a TIME vakváltozó értéke 1 volt akkor, ha az adatfelvételre a botrányok után került sor (vagyis 2015-ben), és 0, ha a NAV-botrányok elött történt az adatfelvétel (vagyis 2013-ban). Emellett a korrupcióészlelés időbeli hatásának vizsgálatára a TIME és a CORRUPTION változók szorzataként létrehoztuk a TIME_ CORRUPTION interakciós változót. A hipotézis tesztelése során azt vizsgáltuk, hogy a TIME, illetve a TIME_CORRUPTION változók szignifikáns hatásúak-e abban az esetben, ha a többi egyébként szignifikáns független változó mellett szerepelnek abban a regressziós modellben, amelynek függő változója a NAV-ba vetett bizalom.

Mindezek mellett az irodalmi áttekintésben tárgyalt tanulmányok elméleti meglátásai és a korábbi empirikus eredmények nyomán további kontrollváltozók használata is indokolt. A NAV-ba vetett bizalom - mint egy specifikus intézmény iránti bizalom - mellett célszerủ a magyar közintézmények iránti általános bizalom vizsgálata is. Ezért létrehoztunk egy olyan indexet, amely a magyar közintézmények iránti bizalom átlagos mutatója (TRUST_PUBLIC) a bíróságokba, az Alkotmánybíróságba, az ügyészségbe, a rendőrségbe, az önkormányzatokba és a Magyar Nemzeti Bankba vetett bizalom átlaga alapján. Az index alapjául szolgáló eredeti változókat négyfokú Likert-skálán mértük, és 1-től 4-ig kódoltuk, így a magyar közintézményi bizalom átlagos indexe is az 1-től 4-ig terjedő skálán vehet fel értéket. Mivel ugyanezen a skálán is mértük a NAV-ba vetett bizalom szintjét (a 11-fokú skála mellett), a magyar adóhatóságba vetett bizalom közvetlenül is összehasonlítható akár az általános magyar közintézményi bizalom szintjével, akár más hazai közintézmények iránt megnyilvánuló bizalom mértékével.

Mint említettük, a korábbi kutatások egyöntetüen azt találták, hogy a közösséggel való azonosulás pozitívan hat az adózási hajlandóságra. Konrad-Qari [2012] rámutatott, hogy a hazafiasság érzése növeli az adózási hajlandóságot. Ezért a magyar politikai közösséggel történő érzelmi azonosulást a nemzeti büszkeség érzésével operacionalizáltuk (NATIONAL PRIDE), ezt a változót ötfokú Likert-skálán mértük, ahol 1 a nemzeti büszkeség nagyon alacsony, 5 pedig nagyon magas értékét fejezi ki. A magyar kormányzat normatív legitimitásának mérésére közelítő változóként a következő állítással történő egyetértés mértékét használtuk: „A kormány mindannyiunk érdekében dolgozik” (GOV_ PUBLIC_INT). A változót ugyancsak ötfokú Likert-skálán mértük, és 1-től (egyáltalán nem ért egyet) 5-ig (teljes mértékben egyetért) kódoltuk.

Végül a magyar állampolgárok normaszegő attitűdjének megragadására is használtunk kontrollváltozókat. Egyrészt rákérdeztünk arra, hogy mennyire értenek egyet azzal az állítással, hogy „Néha áthághatunk törvényeket, ha azok számunkra nagyon kellemetlenek" (BREAKING LAWS) - ezt a változót szintén 1-től 5-ig, az egyetértés 
mértéke alapján kódoltuk. Másrészt megvizsgáltuk azt is, hogy mi a válaszadók percepciója az adózási magatartás szempontjából fontos normaszegésről, a számla kérésének elmulasztásáról a háztartási szerelési-javítási munkák esetében (NON_INVOICE). Itt arra kérdeztünk rá, hogy „Ön szerint milyen gyakran fordul elő Magyarországon, hogy az emberek nem kérnek számlát szerelőtől, szobafestőtől stb.”. Ennél a változónál a válaszokat az előfordulás vélelmezett gyakorisága szerint 1-től 5-ig kódoltuk, ahol az 1 a „szinte soha”, az 5 pedig a „szinte mindig” opcióra utalt.

A változók alapvető leíró statisztikáit, illetve a független változók korrelációs mátrixát a Függelék tartalmazza. Néhány változó ugyanakkor végül nem került be a regressziós modelljeinkbe. Egyrészt kihagytuk a közintézményi bizalom általános indexét (TRUST PUBLIC), mivel a TRUST_PUBLIC és a GOV_PUBLIC_INT változók között a korreláció kiugróan erősnek bizonyult. Mellőztük a regressziós modellekből a NON_INVOICE változót is, mivel ezt a normaszegést válaszadóink többsége valójában normának tekintette: a háztartási szerelési-javítási munkát végző mesterektöl megítélésük szerint a magyar állampolgárok jellemzően nem kérnek számlát - így ezt a változót nem tekinthetjük a normaszegés percepcióját tükröző indikátornak. Úgy tünik, hasonlóan az olaszországi adózási attitüdökhöz (Andrighetto és szerzőtársai [2016]), a kozmetikázási hajlam (fudging) a magyar állampolgárok körében is általános.

$\mathrm{Az}$ 1. нIPOTÉZIs tesztelésére a kényszerü adófizetési motiváció versus önkéntes adófizetési motiváció változóinak páros mintás Student-féle $t$-próbáját használtuk. Négy, legkisebb négyzetek módszerén alapuló (OLS) regressziós modellt futtattunk a 2. HIPOTÉZIS vizsgálatára; a modellek függő változója minden esetben az önkéntes adózási hajlandóság közelítő változója volt. Az 1. modell a független változók közül csak a társadalmi-demográfiai és jövedelmi változókat tartalmazta, a 2. modell emellett a NAV-ba vetett bizalom, továbbá az adóhatóság hatékonyságának és procedurális méltányosságának közelítő változóit is. A 3. modellbe további kontrollváltozók kerültek be: a nemzeti büszkeség, a kormányzat normatív legitimitása, illetve a normaszegő attitüd közelítő változói. Végül a 4. modell annyiban különbözött a harmadiktól, hogy a multikollinearitás minimalizálása érdekében kikerült belőle néhány olyan változó, amely valamely más független változóval erősen korrelált. A 3. HIPOTÉzIs tesztelésekor hasonló eljárást követtünk, azzal az eltéréssel, hogy ebben az esetben a függő változó a kényszerủ adófizetési motiváció közelítő változója volt. A hipotézist tesztelő négy modellnél a független változók bevonása ugyanolyan eljárás szerint történt, mint a 2. HIPOTÉZIS modelljeinél.

A 4. нIPOTÉZIs tesztelésére először egy útmodellt készítettünk azért, hogy feltárjuk a lehetséges oksági utak erősségét, illetve megvizsgáljuk, hogy a NAV-ba vetett bizalom változója tekinthető-e a korábbi regressziós eredmények szerint releváns más független változók, illetve az önkéntes adófizetésre való hajlandóság közötti közvetítő változónak. Ezt követően a 2013-as és a 2015-ös adatfelvételek egyesített adatbázisából három legkisebb négyzetes (OLS) regressziós modellt futtattunk, hogy teszteljük a botrány érzékelésének lehetséges hatását. A függő változó mindhárom modellben a NAV-ba vetett bizalom, a független változók között pedig a társadalmidemográfiai változók, az adóhatóság hatékonyságának és procedurális méltányosságának közelítő változói, illetve a korábban tárgyalt kontrollváltozók szerepelnek. 
A modellek közötti különbség csupán annyi, hogy az 1. modell nem tartalmazza, a 2. és a 3. viszont tartalmazza a TiME változót, illetve a 3. modellbe emellett bevontuk az időtényező és a korrupcióészlelés interakciós változóját is. Így a parciális hatás erőssége révén tesztelhetjük, hogy kimutatható-e olyan szignifikáns hatás a NAV-ba vetett bizalomra, amely nem magyarázható más független változókkal. Ha a TIME változóhoz, illetve a korrupcióészlelés időbeli alakulását kifejező TIME_CORRUPTION interakciós változóhoz tartozó regressziós együttható szignifikáns és negatív valamennyi egyéb független változó mellett is, akkor a NAV-hoz köthető botrányok érdemben rombolták az adóhatóságba vetett bizalmat.

\section{Eredmények}

Bár az adóhatóság szankcióitól való félelem ugyancsak jelentős ösztönző, az önkéntes adófizetési hajlandóság hatása erősebb a magyar állampolgárok adózási attitüdjeiben: az ezt közelítő változó átlagértéke $(3,85)$ és a kényszerü hajlandóság közelítő változójának átlagértéke $(3,12)$ közötti különbség statisztikailag szignifikáns (a Student-féle páros mintás $t$-próba szerint $p<0,001$ megbízhatósági szinten). A kétféle adózási motiváció között nincs szignifikáns kapcsolat; a Spearmanféle rangkorrelációs együttható értéke mindössze 0,02. Mindennek alapján az 1 . HIPOTÉZISÜNKET el kell utasítanunk.

A 2. HIPOTÉZISÜNKET, azaz a magyar állampolgárok önkéntes adófizetési hajlandóságának magyarázatát tesztelő regressziós modelljeink (1. táblázat) arra utalnak, hogy a társadalmi-demográfiai változók hatása mérsékelt: ezek közül a tényezök közül csupán a lakóhely és a jövedelmi helyzet változásának hatása szignifikáns: a városi népesség, illetve a jövedelemi helyzetük kedvezőbb alakulását tapasztalók önkéntes adófizetési motivációi erősebbek (1. modell).

A bizalmi és a procedurális méltányossági tényezöket is tartalmazó 2. modell ugyanakkor azt mutatja, hogy a NAV-ba vetett bizalom, illetve az adóhatóság vélelmezett korrupciója szignifikánsan hatnak az önkéntes adózási hajlandóságra (az előjelek megfelelnek a várakozásoknak: előbbinél pozitív, utóbbinál negatív a hatás iránya).

A további kontrollváltozókat is tartalmazó 3. modell szerint a bizalom és az érzékelt korrupció mellett a nemzeti büszkeség tényezőjének hatása is szignifikáns, és az előjel itt is megfelel a várakozásnak: a csoporthoz, azaz esetünkben a magyar politikai közösséghez tartozás erősebb érzése növeli az önkéntes adózási hajlandóságot.

A multikollinearitást minimalizáló, emiatt a kevesebb változót bevonó 4. modell hasonló magyarázattal szolgál, azonban ebben a modellben a lakóhely hatása ismét szignifikánsnak bizonyul. (Ennek a regressziós modellnek a reziduuma nem korrelál szignifikánsan a 3. modellből kihagyott változók egyikével sem.) Összességében eredményeink egyértelmüen mutatják, hogy a NAV-ba vetett bizalom és az adóhatóság vélelmezett korrupciója alapvetően befolyásolják az önkéntes adózási hajlandóságot a magyar állampolgárok körében. Ennek alapján második hipotézisünket nem kell elvetnünk. A nemzeti büszkeség változójának szignifikáns hatása ugyanakkor kiemeli, hogy az önkéntes adózás késztetésénél a csoporttudat 


\section{1. táblázat}

Az önkéntes adófizetési hajlandóság tényezői 2015-ben Magyarországon

\begin{tabular}{|c|c|c|c|c|}
\hline & 1. modell & 2. modell & 3. modell & 4. modell \\
\hline Konstans & $\begin{array}{l}3,231^{\star *} \\
(0,126)\end{array}$ & $\begin{array}{l}3,155^{\star *} \\
(0,187)\end{array}$ & $\begin{array}{l}2,717^{\star *} \\
(0,211)\end{array}$ & $\begin{array}{l}2,684^{* *} \\
(0,153)\end{array}$ \\
\hline $\operatorname{GENDER}^{a}$ & $\begin{array}{c}0,067 \\
(0,057)\end{array}$ & $\begin{array}{c}0,013 \\
(0,057)\end{array}$ & $\begin{array}{c}0,008 \\
(0,057)\end{array}$ & \\
\hline AGE & $\begin{array}{c}0,001 \\
(0,002)\end{array}$ & $\begin{array}{c}0,001 \\
(0,002)\end{array}$ & $\begin{array}{c}0,000 \\
(0,002)\end{array}$ & \\
\hline EDUCATION $^{b}$ & $\begin{array}{c}0,088 \\
(0,059)\end{array}$ & $\begin{array}{c}0,066 \\
(0,059)\end{array}$ & $\begin{array}{c}0,049 \\
(0,059)\end{array}$ & \\
\hline URBAN $^{c}$ & $\begin{array}{c}0,130^{*} \\
(0,063)\end{array}$ & $\begin{array}{c}0,101 \\
(0,063)\end{array}$ & $\begin{array}{c}0,103 \\
(0,063)\end{array}$ & $\begin{array}{c}0,145^{\star} \\
(0,060)\end{array}$ \\
\hline INCOME_CHANGE_1Y & $\begin{array}{l}0,159^{\star *} \\
(0,033)\end{array}$ & $\begin{array}{c}0,098^{\star *} \\
(0,035)\end{array}$ & $\begin{array}{c}0,082^{*} \\
(0,036)\end{array}$ & $\begin{array}{l}0,090^{\star *} \\
(0,033)\end{array}$ \\
\hline TRUST_NTCA & & $\begin{array}{l}0,069^{* *} \\
(0,013)\end{array}$ & $\begin{array}{l}0,056^{\star *} \\
(0,013)\end{array}$ & $\begin{array}{l}0,045^{\star *} \\
(0,012)\end{array}$ \\
\hline NTCA_EFFECTIVENESS & & $\begin{array}{c}0,019 \\
(0,029)\end{array}$ & $\begin{array}{c}0,006 \\
(0,032)\end{array}$ & \\
\hline DISCRIMINATION & & $\begin{array}{c}-0,012 \\
(0,013)\end{array}$ & $\begin{array}{c}-0,016 \\
(0,013)\end{array}$ & \\
\hline POLITICISATION & & $\begin{array}{c}0,017 \\
(0,015)\end{array}$ & $\begin{array}{c}0,022 \\
(0,015)\end{array}$ & \\
\hline CORRUPTION & & $\begin{array}{c}-0,037^{\star *} \\
(0,014)\end{array}$ & $\begin{array}{c}-0,039^{\star *} \\
(0,014)\end{array}$ & $\begin{array}{c}-0,030^{\star *} \\
(0,011)\end{array}$ \\
\hline NATIONAL PRIDE & & & $\begin{array}{c}0,189^{\star *} \\
(0,029)\end{array}$ & $\begin{array}{l}0,200^{\star *} \\
(0,028)\end{array}$ \\
\hline GOV_PUBLIC_INT & & & $\begin{array}{c}-0,009 \\
(0,033)\end{array}$ & \\
\hline BREAKING LAWS & & & $\begin{array}{c}-0,009 \\
(0,026)\end{array}$ & \\
\hline$N$ & 1164 & 1036 & 1009 & 1068 \\
\hline F-érték & $7,10^{\star *}$ & $10,24^{\star *}$ & $11,46^{\star *}$ & $28,26^{* *}$ \\
\hline$R^{2}$ & 0,030 & 0,091 & 0,130 & 0,117 \\
\hline Korrigált $R^{2}$ & 0,026 & 0,082 & 0,119 & 0,113 \\
\hline
\end{tabular}

Megjegyzés: zárójelben a standard hibák szerepelnek.

${ }^{a}$ Referenciacsoport: férfiak.

${ }^{b}$ Referenciacsoport: alacsonyabb végzettségűek.

${ }^{c}$ Referenciacsoport: nem városi településen élők.

${ }^{\star *} p<0,01,{ }^{\star} p<0,05$ szinten szignifikáns. 
2. táblázat

A kényszerű adófizetési motiváció tényezői 2015-ben Magyarországon

\begin{tabular}{|c|c|c|c|c|}
\hline & 1. modell & 2. modell & 3. modell & 4. modell \\
\hline Konstans & $\begin{array}{l}3,566^{\star *} \\
(0,152)\end{array}$ & $\begin{array}{l}2,840^{\star *} \\
(0,227)\end{array}$ & $\begin{array}{l}2,494^{* *} \\
(0,259)\end{array}$ & $\begin{array}{l}2,764^{* *} \\
(0,166)\end{array}$ \\
\hline GENDER $^{a}$ & $\begin{array}{c}0,093 \\
(0,068)\end{array}$ & $\begin{array}{c}0,095 \\
(0,070)\end{array}$ & $\begin{array}{c}0,130 \\
(0,070)\end{array}$ & \\
\hline AGE & $\begin{array}{l}-0,013^{\star *} \\
(0,002)\end{array}$ & $\begin{array}{l}-0,011^{\star *} \\
(0,002)\end{array}$ & $\begin{array}{l}-0,011^{\star *} \\
(0,002)\end{array}$ & $\begin{array}{c}-0,012^{\star *} \\
(0,002)\end{array}$ \\
\hline EDUCATION $^{b}$ & $\begin{array}{c}-0,054 \\
(0,071)\end{array}$ & $\begin{array}{c}-0,021 \\
(0,072)\end{array}$ & $\begin{array}{c}-0,014 \\
(0,073)\end{array}$ & \\
\hline URBAN $^{c}$ & $\begin{array}{c}-0,135 \\
(0,076)\end{array}$ & $\begin{array}{c}-0,174^{\star} \\
(0,077)\end{array}$ & $\begin{array}{c}-0,168^{*} \\
(0,078)\end{array}$ & $\begin{array}{c}-0,155^{\star} \\
(0,074)\end{array}$ \\
\hline INCOME_CHANGE_1Y & $\begin{array}{c}0,095^{\star} \\
(0,040)\end{array}$ & $\begin{array}{l}0,111^{\star *} \\
(0,042)\end{array}$ & $\begin{array}{c}0,086^{*} \\
(0,044)\end{array}$ & \\
\hline TRUST_NTCA & & $\begin{array}{c}-0,004 \\
(0,016)\end{array}$ & $\begin{array}{c}-0,006 \\
(0,016)\end{array}$ & \\
\hline NTCA_EFFECTIVENESS & & $\begin{array}{l}0,125^{\star *} \\
(0,035)\end{array}$ & $\begin{array}{c}0,074 \\
(0,039)\end{array}$ & $\begin{array}{c}0,072^{*} \\
(0,036)\end{array}$ \\
\hline DISCRIMINATION & & $\begin{array}{c}0,017 \\
(0,016)\end{array}$ & $\begin{array}{c}0,010 \\
(0,016)\end{array}$ & \\
\hline POLITICISATION & & $\begin{array}{c}0,009 \\
(0,019)\end{array}$ & $\begin{array}{c}0,017 \\
(0,019)\end{array}$ & \\
\hline CORRUPTION & & $\begin{array}{c}0,032 \\
(0,017)\end{array}$ & $\begin{array}{c}0,016 \\
(0,018)\end{array}$ & \\
\hline NATIONAL PRIDE & & & $\begin{array}{c}-0,048 \\
(0,036)\end{array}$ & \\
\hline GOV_PUBLIC_INT & & & $\begin{array}{l}0,109^{\star *} \\
(0,041)\end{array}$ & $\begin{array}{l}0,093^{\star *} \\
(0,035)\end{array}$ \\
\hline BREAKING LAWS & & & $\begin{array}{l}0,173^{\star *} \\
(0,032)\end{array}$ & $\begin{array}{l}0,213^{\star *} \\
(0,029)\end{array}$ \\
\hline$N$ & 1141 & 1029 & 1003 & 1106 \\
\hline F-érték & $9,54^{* *}$ & $6,85^{\star *}$ & $8,67^{* *}$ & $23,92^{* *}$ \\
\hline$R^{2}$ & 0,040 & 0,063 & 0,102 & 0,098 \\
\hline Korrigált $R^{2}$ & 0,036 & 0,054 & 0,091 & 0,094 \\
\hline
\end{tabular}

Megjegyzés: zárójelben a standard hibák szerepelnek.

${ }^{a}$ Referenciacsoport: férfiak.

${ }^{b}$ Referenciacsoport: alacsonyabb végzettségüek.

${ }^{c}$ Referenciacsoport: nem városi településen élők.

${ }^{* *} p<0,01,{ }^{*} p<0,05$. 
bizonyos emocionális tényezői hasonlóan erős hatásúak lehetnek, mint a bizalom és a procedurális méltányosság faktorai.

A 3. нIPOTÉZIsÜNK ellenőrzésére alkalmazott regressziók eredményeit a 2. táblá$z a t$ foglalja össze. A kényszerủ adófizetési motivációknál a társadalmi-demográfiai változók közül csupán az életkornak és a szubjektív jövedelmi helyzet alakulásának van szignifikáns hatása: a fiatalabb korcsoportokban és a jövedelmi pozíciójuk javulását megélők körében nagyobb a kényszer motivációs ereje.

Várakozásunknak megfelelően szignifikáns és pozitív a hatása a NAV eredményességével kapcsolatos percepciónak, bár a 3. modellben a hatás - vélhetően a multikollinearitás miatt - gyengébb; a kevesebb változóval müködő 4. modell szerint az adóhatóság észlelt hatékonysága szignifikánsan növeli a kényszerü adófizetési hajlandóságot. A nemzeti büszkeség érzése, az adóhatóságba vetett bizalom, továbbá a NAV-val kapcsolatos méltányossági percepciók (korrupció, politikai hatás, diszkrimináció), vagyis általában azok a morális és affektív változók, amelyek az önkéntes adófizetési hajlandóságot alakítják, viszont nem szignifikánsak a kényszerű adófizetésben. Ezek alapján a 3. HIPOTÉzISÜNKET sem kell elvetnünk. Figyelemre méltó ugyanakkor, hogy a törvények megsértésével kapcsolatos megengedőbb álláspont és a kormányzat legitimitásával kapcsolatos nézet is pozitívan hat a kényszerü adófizetés motivációjára. Ez a látszólagos paradoxon a csúszós lejtő sémájában jól értelmezhető, amennyiben a normaszegésre való hajlam inkább rendpárti, szankcionálással szívesen operáló kormányzati működési módot legitimál.

Mindezek az eredmények igazolják a korábbi kutatások következtetéseit, vagyis azt, hogy Magyarországon is alapvetően más tényezők alakítják az adófizetés kényszerü, illetve önkéntes motivációit. A botrányok negatív hatása elsősorban az önkéntes adófizetési hajlandóságban jelentkezhet, technikai okokból azonban ezt nem tudtuk közvetlenül megvizsgálni. ${ }^{12}$ A gyakorlatban használható függő változó viszont az adóhatóság intézménye iránt megnyilvánuló bizalom, amelyre vonatkozóan explicit kérdés (azonos formában és azonos módon mért változóként) mind a botrányok elötti, 2013-as, mind pedig a botrányokat követő, 2015-ös adatfelvételben szerepelt. A 2015-ös adatfelvétel útelemzési sémája (1. ábra) jól illusztrálja, hogy a NAV-ba vetett bizalom közvetítő változóként is müködik az önkéntes adózás mozgatói, illetve az egyéb magyarázó változók között.

Az útmodell szerint az adóhatóságba vetett bizalom központi szerepet játszik az önkéntes adózási hajlandóság alakításában. Nemcsak közvetlenül, de közvetve is, mivel a NAV vélelmezett hatékonyságát és az eljárási méltányosság érzékelésének szempontjait (az észlelt korrupciót, illetve politizáltságot) és a kormányzat közpolitikai legitimációjának hatását is magában foglalja. Emellett részben a nemzeti büszkeség is az intézményi bizalom csatornáján keresztül fejti ki hatását, bár az emocionális közösségi tudat közvetlen pozitív hatása a bizalom tényezőjénél is erősebb. Szintén szignifikáns az észlelt korrupció közvetlen hatása az önkéntes adózási motivációra, ebben az esetben azonban az adóhatóságba vetett bizalmon keresztül érvényesülő hatás jelentősebb.

\footnotetext{
${ }^{12}$ Mint említettük, a 2013-as adatfelvételben nem szerepelt explicit kérdés az önkéntes adófizetés mozgatórugóira.
} 
1. ábra

Az önkéntes adózási motivációk és az adóhatóság iránti bizalom magyarázó tényezői 2015-ben

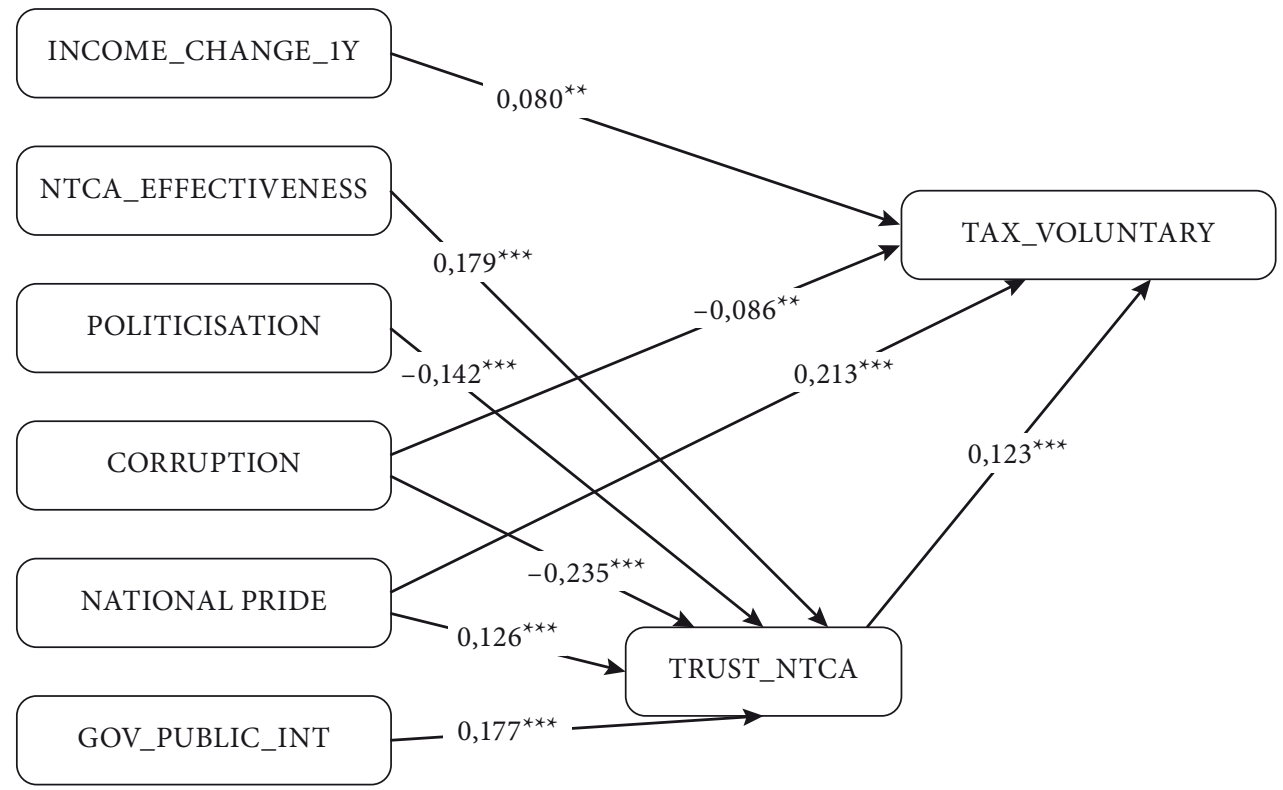

Megjegyzés: az ábra csak a szignifikáns utakat $\left.{ }^{* * *} p<0,001,{ }^{* *} p<0,01,{ }^{*} p<0,05\right)$, illetve a hatások erösségének összehasonlíthatósága céljából a standardizált regressziós együtthatók értékeit mutatja.

A botrányok hatásának tesztelésére (4. HIPOTÉzIS) tehát a 2013-as és a 2015-ös felméréseink egyesített adatbázisán végeztünk regressziós elemzést, amelyben ezúttal az adóhatóságba vetett bizalom a függő változó. A magyarázó változók ugyanazok, mint amelyeket az önkéntes adófizetési hajlandóság kapcsán is használtunk, leszámítva a 2. modellbe bevont TIME változót, illetve a 3. modellbe bevont TIME_CORRUPTION interakciós változót. Az eredményeket a 3. táblázat mutatja.

Várakozásunknak megfelelően a NAV eredményességének kedvezőbb megítélése pozitívan hat az adóhatóság iránti bizalomra. Ugyancsak szignifikáns, de érthető módon negatív a procedurális méltányosság két mutatójának, a korrupció és a politikai befolyás érzékelésének hatása. Az észlelt diszkrimináció azonban ezúttal sem hat a függő változóra. ${ }^{13}$ A kormányzat legitimitása és a nemzeti büszkeség is pozitívan befolyásolja a NAV iránti bizalmat, míg a társadalmi-demográfiai változók közül csupán a nemnek van érdemi hatása: a nők inkább bíznak az adóhatóságban, mint a férfiak.

Az időbeli negatív hatás vitathatatlan: a 2. modellben a TimE változó hatása az összes többi magyarázó változó mellett is szignifikánsnak bizonyult. Ráadásul a

${ }^{13}$ A rendőrségbe vetett bizalmat vizsgáló kutatás ugyancsak azt találta, hogy - a korrupcióval ellentétben - a rendőrség diszkriminatív magatartásának nincs szignifikáns hatása az intézménybe vetett bizalomra (Boda-Medve-Bálint [2015]). Úgy tünik, az intézményi diszkriminációra a magyar állampolgárok nem igazán érzékenyek. 
3. táblázat

Az adóhatóságba vetett bizalom magyarázó tényezői Magyarországon 2013-2015-ben

\begin{tabular}{|c|c|c|c|}
\hline & 1. modell & 2. modell & 3. modell \\
\hline Konstans & $\begin{array}{l}3,085^{\star *} \\
(0,351)\end{array}$ & $\begin{array}{l}3,189^{* *} \\
(0,352)\end{array}$ & $\begin{array}{c}2,712^{\star *} \\
(0,357)\end{array}$ \\
\hline GENDER $^{a}$ & $\begin{array}{l}0,309^{* *} \\
(0,098)\end{array}$ & $\begin{array}{l}0,309^{* *} \\
(0,098)\end{array}$ & $\begin{array}{c}0,312^{\star *} \\
(0,097)\end{array}$ \\
\hline AGE & $\begin{array}{c}-0,002 \\
(0,003)\end{array}$ & $\begin{array}{c}-0,002 \\
(0,003)\end{array}$ & $\begin{array}{c}-0,003 \\
(0,003)\end{array}$ \\
\hline EDUCATION $^{b}$ & $\begin{array}{c}0,014 \\
(0,102)\end{array}$ & $\begin{array}{c}0,014 \\
(0,102)\end{array}$ & $\begin{array}{c}0,016 \\
(0,101)\end{array}$ \\
\hline URBAN $^{c}$ & $\begin{array}{c}-0,118 \\
(0,108)\end{array}$ & $\begin{array}{c}-0,111 \\
(0,108)\end{array}$ & $\begin{array}{c}-0,149 \\
(0,107)\end{array}$ \\
\hline INCOME_CHANGE_1Y & $\begin{array}{c}0,073 \\
(0,060)\end{array}$ & $\begin{array}{c}0,095 \\
(0,060)\end{array}$ & $\begin{array}{c}0,095 \\
(0,059)\end{array}$ \\
\hline NTCA_EFFECTIVENESS & $\begin{array}{l}0,464^{\star *} \\
(0,052)\end{array}$ & $\begin{array}{l}0,462^{\star *} \\
(0,052)\end{array}$ & $\begin{array}{c}0,468^{\star *} \\
(0,051)\end{array}$ \\
\hline DISCRIMINATION & $\begin{array}{c}0,010 \\
(0,022)\end{array}$ & $\begin{array}{c}0,011 \\
(0,022)\end{array}$ & $\begin{array}{c}0,008 \\
(0,021)\end{array}$ \\
\hline POLITICISATION & $\begin{array}{c}-0,081^{\star *} \\
(0,025)\end{array}$ & $\begin{array}{c}-0,081^{\star *} \\
(0,025)\end{array}$ & $\begin{array}{c}-0,070^{\star *} \\
(0,025)\end{array}$ \\
\hline CORRUPTION & $\begin{array}{c}-0,160^{\star *} \\
(0,024)\end{array}$ & $\begin{array}{c}-0,154^{\star *} \\
(0,024)\end{array}$ & $\begin{array}{c}-0,040 \\
(0,030)\end{array}$ \\
\hline NATIONAL PRIDE & $\begin{array}{l}0,304^{* *} \\
(0,050)\end{array}$ & $\begin{array}{l}0,297^{\star *} \\
(0,050)\end{array}$ & $\begin{array}{c}0,299^{* *} \\
(0,049)\end{array}$ \\
\hline GOV_PUBLIC_INT & $\begin{array}{l}0,351^{\star *} \\
(0,054)\end{array}$ & $\begin{array}{l}0,350^{\star *} \\
(0,054)\end{array}$ & $\begin{array}{c}0,358^{\star *} \\
(0,053)\end{array}$ \\
\hline BREAKING LAWS & $\begin{array}{c}-0,103^{*} \\
(0,045)\end{array}$ & $\begin{array}{r}-0,102^{*} \\
(0,045)\end{array}$ & $\begin{array}{c}-0,098^{\star} \\
(0,044)\end{array}$ \\
\hline TIME & & $\begin{array}{c}-0,313^{\star *} \\
(0,098)\end{array}$ & $\begin{array}{c}0,619 \\
(0,177)\end{array}$ \\
\hline TIME_CORRUPTION & & & $\begin{array}{c}-0,225^{\star *} \\
(0,036)\end{array}$ \\
\hline$N$ & 2037 & 2037 & 2037 \\
\hline F-érték & $62,05^{* *}$ & $58,33^{* *}$ & $58,03^{\star *}$ \\
\hline$R^{2}$ & 0,269 & 0,273 & 0,286 \\
\hline Korrigált $R^{2}$ & 0,264 & 0,268 & 0,282 \\
\hline
\end{tabular}

Megjegyzés: zárójelben a standard hibák szerepelnek.

${ }^{a}$ Referenciacsoport: férfiak.

${ }^{b}$ Referenciacsoport: alacsonyabb végzettségűek.

${ }^{c}$ Referenciacsoport: nem városi településen élők.

${ }^{* *} p<0,01,{ }^{*} p<0,05$. 
3. modell szerint a korrupcióészlelés időbeli alakulását kifejező interakciós változó szignifikáns negatív hatása is egyértelmü - minden egyéb tényezőtől függetlenül is. Vagyis kijelenthetjük, hogy 2013 októbere és 2015 márciusa között a magyar adóhatóságba vetett állampolgári bizalom a korrupciós botrányok hatására jelentősen mérséklődött. Figyelemre méltó, hogy eközben más állami intézmények (rendőrség, bíróságok) iránt nem csökkent szignifikánsan az állampolgári bizalom (Boda-Bartha [2015]). Így 4. HIPOTÉZIsÜNKET sem kell elvetnünk: eredményeink szerint a NAV-botrányok negatívan hatottak a magyar állampolgárok önkéntes adófizetési motivációira.

\section{Összegzés, következtetések}

Az adózási magatartás motivációs struktúrája összetett: ennek része ugyan a költségekkel, szankciókkal és kényszerekkel kapcsolatos racionális kalkulus, a viselkedési közgazdaságtan és a gazdaságpszichológia azonban nagyfokú elméleti és empirikus bizonyítékokat szolgáltat arra, hogy az adózást társadalmi viselkedésként értelmezzük. Az adófizetéssel kapcsolatos attitüdöket befolyásolják az egyének társadalmi-demográfiai jellemzői és értékorientációjuk, az adófizetők belső adófizetési motivációját, az adómorált ugyanakkor a közösségi normák és a hatalmat reprezentáló intézmények, mindenekelőtt az adóhatóság működésének észlelt jellemzői is alakítják.

Tanulmányunkban két reprezentatív felmérés alapján a magyar állampolgárok adófizetési motivációit elemeztük. A két adatfelvétel közötti időszakban a magyar adóhatóság müködését korrupciós botrányok árnyékolták be, így vizsgálatunk a NAVbotrányok hatását tesztelő kvázikísérletként is értelmezhető. Eredményeink egyértelmüen arra utalnak, hogy 2013-2015 között a megnövekedett korrupciós percepció hatására szignifikánsan csökkent a NAV-ba vetett bizalom, ez pedig az adómorált is gyengítette. Igaz, a magyar állampolgárok kényszerủ adófizetési motivációi között nincs érdemi szerepük az intézményi bizalom és az eljárási méltányosság tényezőinek, így a korrupciós észlelésnek sem. A kényszerü adófizetést bizonyos társadalmi-demográfiai tényezők mellett elsősorban az adóhatóság hatékonyságáról történő vélekedés ösztönzi, emellett a kozmetikázási hajlam és a mérsékelt normaszegő attitüd sajátos módon rendpártisággal társul. Ebben az összefüggésben az adófizetés biztosítására a technikai kényszerek - mint a NAV információs rendszeréhez közvetlenül bekötött online pénztárgépek - fokozása racionális kormányzati törekvésnek tünik.

Csakhogy eredményeink szerint az önkéntes motivációk - összhangban a nemzetközi kutatási eredményekkel - a magyar állampolgárok adózási attitüdjében is fontosabbak a kényszereknél; az önkéntes adófizetésre pedig a társadalmi-demográfiai tényezők mellett éppen az intézményi bizalomnak, az észlelt korrupciónak és az emocionális politikai közösségtudatnak van kiemelt hatása. A NAV-botrányokkal kapcsolatosan megnövekedett korrupciós percepció ráadásul nemcsak a bizalmat és az adómorált rombolja, de a kozmetikázásra hajlamos állampolgároknak a kényszerek, szankciók legitimitásával kapcsolatos érzetét is csökkenti. Végül heurisztikus viselkedésủ állampolgárokat feltételezve, vélhető, hogy a korrupciós percepció 
gyors, takarékos és negatív hatású heurisztikaként is müködik az adófizetésben, így a megugró korrupció érzetének költségvetési következményei olyan kormányzatok számára is nehezen kezelhetők, amelyek a diszkurzív kormányzási technikákat általában eredményesen alkalmazzák. Ennek a mechanizmusnak a pontosabb megértése ugyanakkor további kutatásokat igényel.

\section{Hivatkozások}

Akerlof, G. A.-Shiller, R. J. [2009]: Animal Spirits: How Human Psychology Drives the Economy, and Why It Matters for Global Capitalism. Princeton University Press, Princeton.

Allingham, M. G.-Sandmo, A. [1972]: Income Tax Evasion: A Theoretical Analysis. Journal of Public Economics, Vol. 1. No. 3-4. 323-338. o. http://dx.doi.org/10.1016/00472727(72)90010-2.

Alm, J.-McClelland, G. H.-Schulze, W. D. [1992]: Why Do People Pay Taxes? Journal of Public Economics, Vol. 48. No. 1. 21-38. o. http://dx.doi.org/10.1016/0047-2727 (92)90040-m.

Andreoni, J.-Erard, B.-Feinstein, J. [1998]: Tax Compliance. Journal of Economic Literature, Vol. 36. No. 2. 818-860. o.

Andrighetto, G.-Zhang, N.-Ottone, S.-Ponzano, F. -D’Attoma, J. -Steinmo, S. [2016]: Are some countries more honest than others? Evidence from a tax compliance experiment in Sweden and Italy. Frontiers in psychology, Vol. 7. Article 472. http://dx.doi.org/10.3389/ fpsyg.2016.00472.

Ariely, D. [2008]: Predictably Irrational: The Hidden Forces That Shape Our Decisions. HarperCollins, New York.

Ariely, D. [2012]: The (Honest) Truth About Dishonesty: How We Lie to Everyone - Especially Ourselves. HarperCollins, New York.

BÁNfi TAmás [2014]: Igazságos adó(rendszer) vagy etikus adózó Megjelent: Igazságos adó(rendszer) vagy etikus adózó Köz-Gazdaság, 9. évf. 4. sz. Különszám az adópolitikáról, 99-108. o. http://unipub.lib.uni-corvinus.hu/1831/1/KG_2014n4_Banfi_p99.pdf.

Becker, G. S. [1968]: Crime and Punishment. An Economic Approach. Journal of Political Economy, Vol. 76. No. 2. 169-217. o. http://dx.doi.org/10.1086/259394.

Benedek Dóra-Lelkes Orsolya [2006]: A magyarországi jövedelem-újraelosztás és egy egykulcsos adóreform vizsgálata mikroszimulációs modellel. Közgazdasági Szemle, 53. évf. 7-8. sz. 604-623. o.

Bird, R. M.-Martinez-Vazquez, J.-Torgler, B. [2008]: Tax Effort in Developing Countries and High Income Countries: The Impact of Corruption, Voice and Accountability. Economic Analysis and Policy, Vol. 38. No. 1. 55-71. o. http://dx.doi.org/10.1016/s03135926(08)50006-3.

Boda Zsolt-Bartha Attila [2015]: Adófizetési hajlandóság és bizalom. Megjelent: Boda Zsolt (szerk.): Bizalom és közpolitika. Jobban működnek-e az intézmények, ha bíznak bennük? Argumentum-MTA Társadalomtudományi Kutatóközpont Politikatudományi Intézet, Budapest, 97-112. o.

Boda Zsolt-Medve-BÁlint Gergő [2014]: Does Institutional Trust in East Central Europe Differ from Western Europe? European Quarterly of Political Attitudes and Mentalities, Vol. 3. No. 2. 1-17. o. 
Boda Zsolt-Medve-Bálint Gergő [2015]: A rendőrségbe vetett bizalom tényezői. Megjelent: Boda Zsolt (szerk.) Bizalom és közpolitika. Jobban müködnek-e az intézmények, ha bíznak bennük? Argumentum-MTA Társadalomtudományi Kutatóközpont Politikatudományi Intézet, Budapest. 75-94. o.

Bowles, S.-Hwang, S.-H. [2008]: Social preferences and public economics: Mechanism design when social preferences depend on incentives. Journal of Public Economics, Vol. 92. No. 8-9. 1811-1820. o. http://dx.doi.org/10.1016/j.jpubeco.2008.03.006

Braithwaite, V. [2002]: Dancing with Tax Authorities: Motivational Postures and Noncompliant Actions. Megjelent: Braithwaite, V. (szerk.): Taxing Democracy. Ashgate, Aldershot. 15-39. o.

Donnelly, M.-Pop-Eleches, G. [2012]: The Questionable Validity of Income Measures in the World Values Survey. Paper prepared for the Princeton University Political Methodology Seminar, március 16. http://www.princeton.edu/politics/about/file-repository/public/ DonnellyPopElechesMarch16.pdf.

Feld, L. P.-Frey, B. S. [2002]: Trust breeds trust: How taxpayers are treated. Economics of Governance, Vol. 3. No. 2. 87-99. o. http://dx.doi.org/10.1007/s101010100032.

Feld, L. P.-Frey, B. S. [2007]: Tax compliance as the result of a psychological tax contract: The role of incentives and responsive regulation. Law \& Policy, Vol. 29. No. 1. 102-120. o. http://dx.doi.org/10.1111/j.1467-9930.2007.00248.x.

Frey, B. [1997]: Not Just for the Money. An Economic Theory of Personal Motivation. Edward Elgar, Cheltenham.

Frey, B. S.-TorgleR, B. [2007]: Tax morale and conditional cooperation. Journal of Comparative Economics, Vol. 35. No. 1. 136-159. o. http://dx.doi.org/10.1016/j.jce.2006.10.006.

Frey, B. S.-Weck-Hannemann, H. [1984]: The Hidden Economy as an 'Unobserved' Variable. European Economic Review, Vol. 26. No. 1. 33-53. o. http://dx.doi.org/10.1016/00142921(84)90020-5.

Gigerenzer, G.-Todd, P. M.-ABC Research Group [1999]: Simple Heuristics that Make Us Smart. Oxford University Press, New York.

Gulyás LÁszló- Máhr Tamás-Tóth István János [2015]: Factors to Curb Tax Evasion: Evidence from the TAXSIM Agent-Based Simulation Model. Discussion papers MT-DP 2015/21. MTA KRTK KTI, Budapest, http://econ.core.hu/file/download/mtdp/MTDP1521.pdf.

GYőRfFy Dóra [2012]: Intézményi bizalom és a döntések időhorizontja. Közgazdasági Szemle, 59. évf. 4. sz. 412-425. o.

Halla, M. [2012]: Tax morale and compliance behavior: First evidence on a causal link. The B.E. Journal of Economic Analysis \& Policy, Vol. 12. No. 1. 1-27. o. http://dx.doi. org/10.1515/1935-1682.3165

Hanousek, J.-PALDA, F. [2004]: Quality of government services and the civic duty to pay taxes in the Czech and Slovak Republics, and other transition countries. Kyklos, Vol. 57. No. 2. 237-252. o. http://dx.doi.org/10.1111/j.0023-5962.2004.00252.x.

Hartner, M.-Rechberger, S.-Kirchler, E.-Schabmann, A. [2008]: Procedural fairness and tax compliance. Economic Analysis and Policy, Vol. 38. No. 1. 137-152. o. http://dx.doi. org/10.1016/s0313-5926(08)50010-5.

HAWDON, J. [2008]: Legitimacy, trust, social capital, and policing styles: A theoretical statement. Police Quarterly, Vol. 11. No. 2. 182-201. o. http://dx.doi.org/10.1177/1098611107311852.

Hochman, G.-Ayal, S.-Ariely, D. [2015]: Fairness requires deliberation: the primacy of economic over social considerations. Frontiers in psychology, Vol. 6. Article 747. http:// dx.doi.org/10.3389/fpsyg.2015.00747. 
Hofmann, E.-Hoelzl, E.-Kirchler, E. [2008]: Preconditions of voluntary tax compliance: Knowledge and evaluation of taxation, norms, fairness, and motivation to cooperate. Zeitschrift Für Psychologie/Journal of Psychology, Vol. 216. No. 4. 209-217. o. http:// dx.doi.org/10.1027/0044-3409.216.4.209.

Kahan, D. M. [2001]: Trust, Collective Action, and Law. Boston University Law Review, Vol. 81. No. 2. 333-347. o.

Kirchler, E. [2007]: The Economic Psychology of Tax Behaviour. Cambridge University Press, New York.

Kirchler, E.-Hoelzl, E.-WAhl, I. [2008]: Enforced versus Voluntary Tax Compliance: The "Slippery Slope" Framework. Journal of Economic Psychology, Vol. 29. No. 2. 210-225. o. http://dx.doi.org/10.1016/j.joep.2007.05.004

Kogler, C.-Batrancea, L.-Nichita, A.-Pantya, J.-Belianin, A.-Kirchler, E. [2013]: Trust and power as determinants of tax compliance: Testing the assumptions of the slippery slope framework in Austria, Hungary, Romania and Russia. Journal of Economic Psychology, Vol. 34. 169-180. o. http://dx.doi.org/10.1016/j.joep.2012.09.010.

Konrad, K. A.-QARI, S. [2012]: The last refuge of a scoundrel? Patriotism and tax compliance. Economica, Vol. 79. No. 315. 516-533. o. http://dx.doi.org/10.1111/j.1468-0335.2011.00900.x KorNAI JánOs [1996]: Négy jellegzetesség. (A magyar fejlődés politikai gazdaságtani megközelítésben. Második rész.) Közgazdasági Szemle, 43. évf. 1. sz. 1-29. o.

Lago-Peñas, I.-Lago-Peñas, S. [2010]: The Determinants of Tax Morale in Comparative Perspective: Evidence from European Countries. European Journal of Political Economy, Vol. 26. No. 4. 441-453. o. http://dx.doi.org/10.1016/j.ejpoleco.2010.06.003

LeVenthal, G. S. [1980]: What should be done with equity theory? Megjelent: Gergen, K. J.Greenberg, M. S.-Willis, R. H. (szerk.): Social Exchange: Advances in Theory and Research. Springer, Heidelberg. 27-55. o.

Méder Zsombor Zoltán-Simonovits András-Vincze János [2012]: Adómorál és adócsalás - társadalmi preferenciák és korlátozott racionalitás. Közgazdasági Szemle, 59. évf. 10. sz. 1086-1106. o.

Muehlbacher, S.-Kirchler, E.-SchWARZEnberger, H. [2011]: Voluntary versus enforced tax compliance: Empirical evidence for the "slippery slope" framework. European Journal of Law and Economics, Vol. 32. No. 1. 89-97. o. http://dx.doi.org/10.1007/s10657-011-9236-9.

Murphy, K. [2004]: The role of trust in nurturing compliance: A study of accused tax avoiders. Law and Human Behavior, Vol. 28. No. 2. 187-209. o. http://dx.doi.org/10.1023/ b:lahu.0000022322.94776.ca.

Murphy, K. [2005]: Regulating More Effectively: The Relationship between Procedural Justice, Legitimacy, and Tax Non-compliance. Journal of Law and Society, Vol. 32. No. 4. 562-589. o. http://dx.doi.org/10.1111/j.1467-6478.2005.00338.x.

Pesuth Tamás [2014]: Adópolitikai változások a válság után. A bankadók térnyerése. Megjelent: Igazságos adó(rendszer) vagy etikus adózó. Köz-Gazdaság, 9. évf. 4. sz. Különszám az adópolitikáról. 145-158. o. http://www.uni-corvinus.hu/fileadmin/user_upload/hu/ kozgazdasagtudomanyi_kar/files/Koz_gazdasag/IX._evfolyam_4.szam_2014._december/ Pesuth_145-158.pdf.

SCHмÖLders, G. [1960]: Das Irrationale in der öffentlichen Finanzwirtschaft. Suhrkamp, Frankfurt am Main.

Simonovits András [2013]: Does Higher Tax Morale Imply Higher Optimal Labor Income Tax Rate? Danube: Law and Economics Review, Vol. 4. No. 2. 97-114. o. http://dx.doi. org/10.2478/danb-2013-0005. 
Slemrod, J.-Yitzhaki, S. [2002]: Tax Avoidance, Evasion, and Administration. Megjelent: Auerbach, A. J.-Feldstein, M. (szerk.): Handbook of Public Economics, Vol. 3. Elsevier, Amszterdam, 1423-1470. o.

SzÁntó Zoltán-Tóth István János [2001]: A rejtett gazdaság és az ellene való fellépés tényezői. Közgazdasági Szemle, 48. évf. 3. sz. 203-218. o.

Torgler, B. [2003]: Tax morale in transition countries. Post-Communist Economies, Vol. 15. No. 3. 357-381. o. http://dx.doi.org/10.1080/1463137032000139052.

Torgler, B. [2005]: Tax morale and direct democracy. European Journal of Political Economy, Vol. 21. No. 2. 525-531. o. http://dx.doi.org/10.1016/j.ejpoleco.2004.08.002

Torgler, B. [2012]: Tax morale, Eastern Europe and European enlargement. Communist and Post-Communist Studies, Vol. 45. No. 1. 11-25. o. http://dx.doi.org/10.1016/j. postcomstud.2012.02.005.

Torgler, B.-Schneider, F. [2007]: What shapes attitudes toward paying taxes? Evidence from multicultural European countries. Social Science Quarterly, Vol. 88. No. 2. 443-470. o. http://dx.doi.org/10.1111/j.1540-6237.2007.00466.x.

Tyler, T. R. [1990]: Why People Obey the Law. Princeton University Press, Princeton.

Tyler, T. R. [2011]: Why People Cooperate: The Role of Social Motivations. Princeton University Press, Princeton.

Wahl, I.-Kastlunger, B.-Kirchler, E. [2010]: Trust in authorities and power to enforce tax compliance: An empirical analysis of the "Slippery Slope Framework". Law \& Policy, Vol. 32. No. 4. 383-406. o. http://dx.doi.org/10.1111/j.1467-9930.2010.00327.x.

Wenzel, M. [2005]: Motivation or rationalisation? Causal relations between ethics, norms and tax compliance. Journal of Economic Psychology, Vol. 26. No. 4. 491-508. o. http:// dx.doi.org/10.1016/j.joep.2004.03.003

Zmerli, S.-Newton, K. [2008]: Social Trust and Attitudes toward Democracy. Public Opinion Quarterly, Vol. 72. No. 4. 706-724. o. http://dx.doi.org/10.1093/poq/nfn054. 


\section{Függelék}

\section{F1. táblázat}

A változók fő leíró statisztikai mutatói

\begin{tabular}{|c|c|c|c|c|c|}
\hline Változók & Minimum & Maximum & Átlag & Szórás & $\begin{array}{c}\text { Megfigyelések } \\
\text { száma }(N)\end{array}$ \\
\hline \multicolumn{6}{|l|}{ 2015-ös adatbázis } \\
\hline TAX_CONSTRAINED & 1 & 5 & 3,85 & 0,97 & 1167 \\
\hline TAX_VOLUNTARY & 1 & 5 & 3,12 & 1,16 & 1143 \\
\hline TRUST_NTCA & 0 & 10 & 5,23 & 2,68 & 1185 \\
\hline GENDER & 0 & 1 & 0,54 & 0,50 & 1200 \\
\hline AGE & 18 & 91 & 48,23 & 17,23 & 1198 \\
\hline AGECAT & 1 & 4 & 2,43 & 1,08 & 1198 \\
\hline EDUCATION & 0 & 1 & 0,49 & 0,50 & 1199 \\
\hline URBAN & 0 & 1 & 0,70 & 0,46 & 1200 \\
\hline INCOME_CHANGE_1Y & 1 & 5 & 2,53 & 0,86 & 1198 \\
\hline NTCA_EFFECTIVENESS & 1 & 5 & 2,99 & 1,10 & 1174 \\
\hline DISCRIMINATION & 0 & 10 & 5,30 & 2,81 & 1147 \\
\hline POLITICISATION & 0 & 10 & 5,84 & 2,72 & 1148 \\
\hline CORRUPTION & 0 & 10 & 4,39 & 2,73 & 1105 \\
\hline NATIONAL PRIDE & 1 & 5 & 3,79 & 1,01 & 1194 \\
\hline GOV_PUBLIC_INT & 1 & 5 & 2,77 & 1,12 & 1187 \\
\hline TRUST_PUBLIC & 1 & 4 & 2,42 & 0,66 & 1114 \\
\hline BREAKING LAWS & 1 & 5 & 2,66 & 1,13 & 1173 \\
\hline NON_INVOICE & 1 & 5 & 3,61 & 1,08 & 1134 \\
\hline \multicolumn{6}{|c|}{ 2013-as és 2015-ös egyesített adatbázis } \\
\hline TRUST_NTCA & 0 & 10 & 5,46 & 2,59 & 2359 \\
\hline GENDER & 0 & 1 & 0,54 & 0,50 & 2400 \\
\hline AGE & 18 & 109 & 48,24 & 17,23 & 2398 \\
\hline AGECAT & 1 & 4 & 2,43 & 1,08 & 2398 \\
\hline EDUCATION & 0 & 1 & 0,49 & 0,50 & 2398 \\
\hline URBAN & 0 & 1 & 0,70 & 0,46 & 2400 \\
\hline INCOME_CHANGE_1Y & 1 & 5 & 2,46 & 0,89 & 2393 \\
\hline NTCA_EFFECTIVENESS & 1 & 5 & 3,05 & 1,11 & 2357 \\
\hline DISCRIMINATION & 0 & 10 & 5,10 & 2,81 & 2265 \\
\hline POLITICISATION & 0 & 10 & 5,68 & 2,72 & 2282 \\
\hline CORRUPTION & 0 & 10 & 4,10 & 2,71 & 2179 \\
\hline NATIONAL PRIDE & 1 & 5 & 3,83 & 1,04 & 2381 \\
\hline GOV_PUBLIC_INT & 1 & 5 & 2,78 & 1,17 & 2376 \\
\hline TRUST_PUBLIC & 1 & 4 & 2,42 & 0,62 & 2076 \\
\hline BREAKING LAWS & 1 & 5 & 2,64 & 1,14 & 2351 \\
\hline NON_INVOICE & 1 & 5 & 3,67 & 1,04 & 2279 \\
\hline TIME & 0 & 1 & 0,50 & 0,50 & 2400 \\
\hline
\end{tabular}




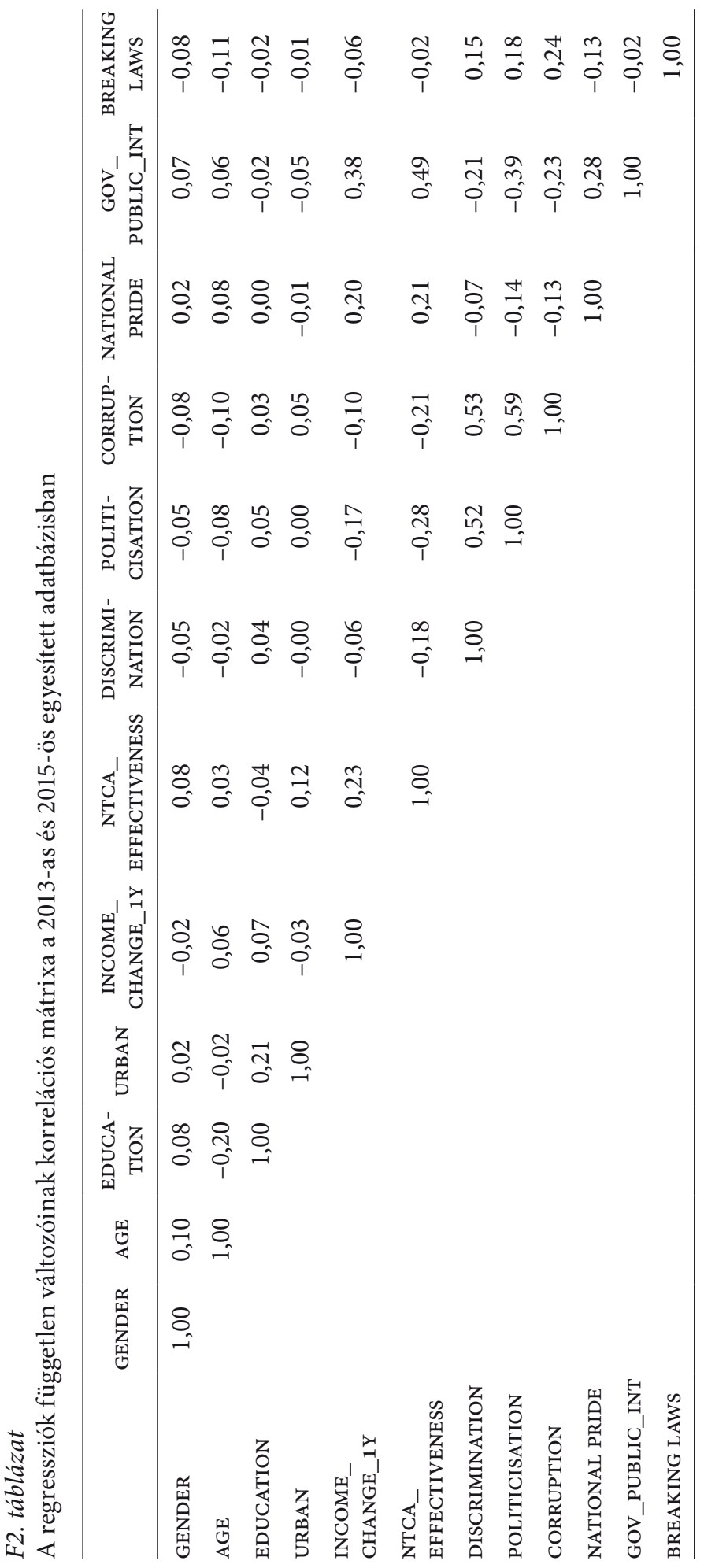

